\title{
Nutrients and organic matter in a glacial river-floodplain system (Val Roseg, Switzerland)
}

\author{
Klement Tockner ${ }^{1}$ \\ Department of Limnology, EAWAG/ETH, 8600 Dübendorf, Switzerland
}

\section{Florian Malard}

UMR CNRS 5023-Ecologie des Hydrosystèmes Fluviaux, Hydrobiologie et Ecologie Souterraines, Université Claude Bernard-Lyon 1, 69622 Villeurbanne Cedex, France

\section{Urs Uehlinger and J. V. Ward}

Department of Limnology, EAWAG/ETH, 8600 Dübendorf, Switzerland

\begin{abstract}
Nutrient and organic matter dynamics were evaluated for a glacial river-floodplain system in the Swiss Alps (Val Roseg). Glacial melt water was the primary source of particulate organic and inorganic matter; hillslope groundwater was richest in $\mathrm{DOC}$ and $\mathrm{SiO}_{2}$; and pulses in dissolved nitrogen were identified during spring snowmelt. Calculations of temporal coherency revealed that hydrological processes within the catchment-floodplain complex controlled nutrient and organic matter species along the main channel; however, local hydrological and/or biogeochemical processes played a major controlling role in most floodplain channels. DON and $\mathrm{NO}_{3}-\mathrm{N}$ were the only variables that were in average significantly correlated across all sampling sites. Comparisons of measured concentrations and concentrations based on a two end member mixing model indicated that the floodplain served as a major sink for particulate phosphorous and suspended matter but was never a source for nutrients or organic matter. Annual areaspecific export rates from the Val Roseg catchment were $7.6 \mathrm{~kg} \mathrm{ha}^{-1} \mathrm{yr}^{-1}$ for TOC (47\% DOC), $4.3 \mathrm{~kg}$ for TP ( $98 \%$ particulate phosphorus), and $4.1 \mathrm{~kg}$ for $\mathrm{TN}\left(78 \% \mathrm{NO}_{3}-\mathrm{N}\right)$.
\end{abstract}

Quantification of nutrient and organic matter sources, transformations, and sinks at the catchment/floodplain scale is a major challenge in ecology. This is in particular true for remote arctic and high alpine streams that have received much less attention compared to more accessible areas (Milner and Petts 1994; Wissmar et al. 1997). Alpine and arctic streams appear resource limited in terms of both nutrients and organic matter. For example, Lock et al. (1990) showed that the addition of phosphorous to an arctic river resulted in a substantial stimulation of both heterotrophic and autotrophic processes. Robinson and Gessner (2000) demonstrated that nutrient addition accelerated leaf breakdown in a glacial stream. Further, there is strong evidence that zoobenthic communities in glacial streams are not solely structured by temperature and channel stability (cf. Milner and Petts 1994), but are strongly influenced by seasonal shifts in water sources and corresponding availability of nutrients and or-

\footnotetext{
${ }^{1}$ Corresponding author (tockner@eawag.ch).
}

\section{Acknowledgements}

This study was supported by a research grant from the Swiss National Science Foundation (SNF 21-49243). We appreciate the field support of Tina Boesch, Birgit Klein, Chris Robinson, Rainer Zah, and Peter Burgherr, and we are especially grateful to Richard Illi and Bruno Ribi for the chemical analyses. We express our sincere thanks to Plenio Testa and his crew at the 'Hotel Roseg' for their hospitality and to the communes of Pontresina and Samedan for providing access to the sampling area. We also appreciate helpful comments by Jürg Zobrist, Edith Kaiser, and Chris Robinson. Thoughtful comments by two anonymous reviewers are gratefully acknowledged. ganic matter (Ward 1994; Füreder 1999; Burgherr and Ward in press).

In unglaciated arctic and alpine streams, snowmelt constitutes the single most important hydrological and geochemical event (Everett et al. 1989; Brooks and Williams 1999; Suecker et al. 2000). Snowmelt frequently is associated with major pulses in nutrients and organic matter, particularly in dissolved inorganic nitrogen (Brooks and Williams 1999; Sickmann et al. 2001). Glacial rivers, however, have two distinct hydrological events, snowmelt and glacial melt, that result in an extended flood pulse (e.g., Collins 1981). Glacial melt water carries high amounts of suspended matter, and specific conductance is generally very low. Proglacial floodplains, characteristic geomorphic features of many glacial rivers, have attracted only minor interest in alpine stream ecology until recently (Tockner et al. 1997; Malard et al. 1999; Ward et al. 1999). There, the interaction between processes acting at the catchment scale (snow melting and glacial runoff) and the floodplain scale (e.g., upwelling of groundwater) increases the complexity of nutrient and organic matter dynamics. Overall, the nutrient and organic matter composition of river-floodplain systems depends on the source of water and the biogeochemical transformations that occur in the floodplain/catchment system. However, it remains contentious whether the processes of transformation and retention operating in headwater systems or proglacial areas are analogous to those in large floodplains (Tockner et al. 2000). Most investigations of floodplain systems have been carried out in large lowland rivers, such as the Amazon, the Orinoco, and the Mackenzie delta (Junk et al. 1989; Lew- 
is et al. 1990; Lesack et al 1998). The flood pulse concept (Junk et al. 1989) recognizes floods as a major driver for river-floodplain dynamics, with periodic fluctuations in water level controlling exchanges of organic matter and nutrients (e.g., Robertson et al. 1999).

In previous studies (Ward et al. 1999; Malard et al. 1999) we analyzed seasonal changes in the relative contribution of different water sources to the flow of surface water within a glacial floodplain of the Swiss Alps (Val Roseg, Switzerland) using natural chemical tracers. In the present paper we examine the spatiotemporal patterns of nutrients and organic matter in this glacial floodplain. The primary goals are to detect seasonal shifts in nutrients and organic matter, to address the role of the glacial floodplain as a sink and source, and to calculate total loads. Further, we demonstrate shifts in organic matter and nutrients across a river-floodplain connectivity gradient and along the main channel of the river, from the glacial snout downstream to the mouth. Temporal coherence (synchrony) between sites along the main stem and across a floodplain gradient was calculated in order to estimate the relative importance of local and regional influences on nutrients and organic matter (e.g., Soranno et al. 1999).

\section{Study site}

The Roseg River, a $11.3 \mathrm{~km}$ long second-order tributary of the River Inn, is situated in the Bernina Massif of the Swiss Alps $\left(9^{\circ} 53^{\prime} 57^{\prime \prime} \mathrm{E}, 4^{\circ} 29^{\prime} 29^{\prime \prime} \mathrm{N}\right.$; Fig. 1a). Its catchment covers an area of $66.5 \mathrm{~km}^{2}$ with elevations ranging from 1,760 to 4,049 $\mathrm{m}$ above sea level. Glaciers, exposed rock, a rock-soil complex supporting herbaceous vegetation, and subalpine forests occupy $30,40,9$, and $21 \%$, respectively, of the catchment area (Fig. 1b). Bedrock consists exclusively of crystalline rock, primarily diorite and granite (Malard et al. 1999). Average annual precipitation is approximately 1.6 $\mathrm{m}$, of which about half falls as snow (1955-1994). Mean annual discharge of the Roseg River is $2.76 \mathrm{~m}^{3} \mathrm{~s}^{-1}$ (Swiss National Hydrological and Geological Survey). The primary water sources are two valley glaciers (Roseg and Tschierva) that have experienced an almost continuous retreat during the last $120 \mathrm{yr}$ (more than $1 \mathrm{~km}$ each). The medial moraine of the two glaciers has dammed the branch from the Roseg glacier and caused the formation of a natural lake about 40 years ago (Fig. 1b). This recently formed lake is expected to modify longitudinal patterns of nutrients and organic matter since it acts as a major trap for suspended matter.

The area of the glacial floodplain (Fig. 1c) is $0.67 \mathrm{~km}^{2}$, $85 \%$ of which is covered by unstable gravel with sporadic pioneer plants (dominant species: Epilobium fleischerii, $R u$ mex scutatus, Trifolium repens). The upper section of the floodplain is steeper (slope: $4.8 \%$ ) and wider (up to $510-\mathrm{m}$ wide) than the lower section (average slope: $1.9 \%$, width 130-260 m, Fig. 1c). Several distinct channel types can be distinguished within the floodplain, including the main channel and upstream connected side channels, subsurface-connected (seepage-fed) and disconnected (hillslope groundwater fed) channels. Tockner et al. (1997) and Malard et al. (1999) described the catchment and the floodplain in detail. a

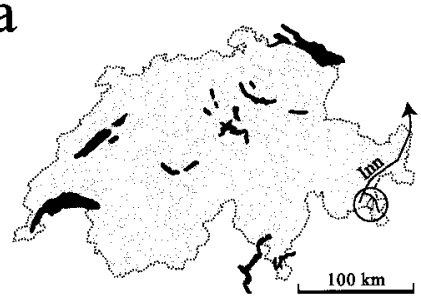

b

$4049 \mathrm{~m}$ a.s. 1
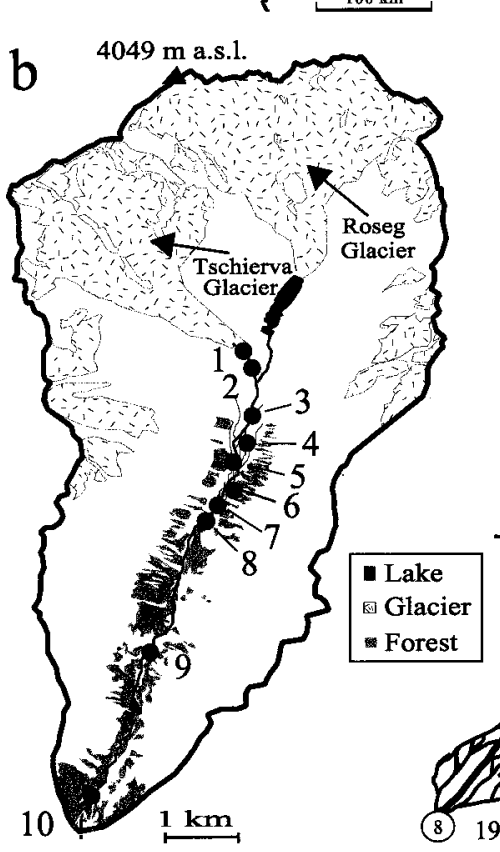

c

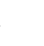

Fig. 1. (a) Geographical location of the Val Roseg catchment (encircled) in the Bernina Massif of the Swiss Alps. (b) Catchment area of the Val Roseg and indication of glaciers, lakes, and forests. Black circles mark sampling sites (sites 1-10) along the main channel. (c) Val Roseg floodplain channel network and location of sampling sites. Sites 3-8, sampling sites along the main channel; H1H3, disconnected groundwater channels fed by hillslope groundwater; A1-A3, subsurface-connected channels fed by alluvial groundwater; U1-U2, upstream connected channels (see text for further explanation).

\section{Materials and methods}

Sampling procedure-Sampling site selection was based on (a) obtaining samples from different floodplain channel types representing a lateral connectivity gradient; and (b) having a network of sites distributed along the entire river corridor (Fig. 1b). Eighteen sites, 10 along the main channel (sites 1-10) and eight representing a lateral river-floodplain gradient, were used in the present analysis. Three different types of water bodies (three sites of each type) were separated within the floodplain: (a) hillslope groundwater channels (disconnected waters fed by the hillslope aquifer; H1, $\mathrm{H} 2$, H3); (b) sites fed by either alluvial groundwater or subsurface seepage water from the main channel (subsurfaceconnected channels; A1, A2, A3), and (c) surface-connected channels, including one main channel site and two sites permanently connected to the main channel at their upstream ends (sites 7, U1, and U2). For comparison with published work, sites numbered 1 to 10 correspond to codes M-15, M- 
10, M-1, M5, M10, M12, M15, M20, M30, and M40 used in previous papers (Tockner et al. 1997; Malard et al. 1999, 2000). Sites H1, H2, H3 correspond to G1, G5, G8; sites A1, A2, A3 correspond to G2, G3, and G4, and, sites U1 and U2 correspond to X3 and S3 (Malard et al. 1999, 2000).

Samples were taken at monthly intervals from February 1997 to January 1998. Because of seasonal changes in the extent of the channel network, some sites lacked surface water in winter (e.g., sites 4 and 5, December-March). During the main ice ablation period in summer, all samples were collected from $0600 \mathrm{~h}$ to $0900 \mathrm{~h}$ in order to avoid changes in water chemistry associated with daily discharge fluctuations.

Chemical analyses-Surface water was collected in 1-liter clean polyethylene bottles, filtered (preashed Whatman GF/ F filters; $0.7 \mu \mathrm{m}$ ) within 1 to $4 \mathrm{~h}$, and stored for 1 to $3 \mathrm{~d}$ at $4^{\circ} \mathrm{C}$ prior to analysis. Specific conductance was measured in the field with a conductivity meter (WTW LF 323-B/Set; reference temperature $20^{\circ} \mathrm{C}$ ). Snowpack was sampled from November 1996 to May 1997 (six dates, $n=18$ ) by digging pits to the ground level and collecting depth-integrated samples in a 3-liter clean polyethylene bottle. The snow $10 \mathrm{~cm}$ above the ground surface was not sampled to avoid possible contamination from soil or overland flow. Because the snow/ water equivalence of the samples was not determined, concentrations are reported per liter of snowmelt water (see Malard et al. 1999).

The amount of total suspended solids (TSS) and volatile suspended solids (POM, AFDM) was determined according to American Public Health Association (APHA 1989). Concentrations of inorganic suspended solids (ISS) were calculated as the difference between TSS and AFDM. Sodium (Na) was measured by inductively coupled plasma-optical emission spectrometry (SPECTRO Analytical Instruments). Silicate $\left(\mathrm{SiO}_{2}\right)$ was determined by the heteropoly blue method (APHA 1989). Soluble reactive phosphorous (SRP) was analyzed according to the molybdenum blue method. Total dissolved phosphorous (TDP) was determined as SRP after digestion with $\mathrm{K}_{2} \mathrm{~S}_{2} \mathrm{O}_{8}$ at $121^{\circ} \mathrm{C}$, and dissolved nonreactive phosphorous (DNP) was calculated as the difference between TDP and SRP. Nitrite $\left(\mathrm{NO}_{2}-\mathrm{N}\right)$ was measured by spectrophotometry after diazotizing with sulfanilamide and coupling with N-(1-naphthyl)-ethylenediamine (Rodier 1996). Ammonium $\left(\mathrm{NH}_{4}-\mathrm{N}\right)$ and nitrate $\left(\mathrm{NO}_{3}-\mathrm{N}\right)$ were measured with the indophenol-blue method and the automated hydrazine reduction method (Downes 1978), respectively. The same method was used to determine total dissolved nitrogen (TDN) after all nitrogen forms had been oxidized to nitrate with $\mathrm{K}_{2} \mathrm{~S}_{2} \mathrm{O}_{8}$ at $121^{\circ} \mathrm{C}$ (Ebina et al. 1983). Dissolved organic nitrogen (DON) was calculated as the difference between TDN and the total amount of inorganic nitrogen (ammonium, nitrite, and nitrate). Particulate phosphorus (PP) and particulate nitrogen (PN) were quantified as SRP and $\mathrm{NO}_{3}-\mathrm{N}$, respectively, after digestion with $\mathrm{K}_{2} \mathrm{~S}_{2} \mathrm{O}_{8}$ at $121^{\circ} \mathrm{C}$. Particulate organic carbon (POC) was determined by high-temperature combustion at $880^{\circ} \mathrm{C}$ with a Horiba infrared detector. Dissolved organic carbon (DOC) was measured by wet oxidation with subsequent acidification and $\mathrm{CO}_{2}$ infrared detection. TOC (total organic carbon) was calculated as the sum of POC and DOC. Total inorganic carbon (TIC) was measured as $\mathrm{CO}_{2}$ with a Horiba infrared detector after samples had been acidified and heated to $880^{\circ} \mathrm{C}$. A detailed description of all analytical methods is given by Malard et al. (1999).

Lateral and longitudinal patterns and temporal coherency (synchrony)-Seasonal changes of total nitrogen (TN), total phosphorous (TP), and total organic carbon (TOC) with the degree of hydrological connectivity was assessed by a twoway analysis of variance (ANOVA). Post hoc comparisons were performed using Tukey test. All statistical analyses were carried out on $\log _{10}(x+1)$ transformed data, which met assumptions of normality and homogenous variances in the data.

Synchrony was used to assess the seasonal patterns in river-floodplain dynamics. Synchrony or temporal coherence is a measure of the similarity between a pair of sampling sites (e.g., Soranno et al. 1999). High synchrony is generated when sites respond similarly to a common driver. For each variable, synchrony was calculated as the Pearson productmoment correlation coefficient $(r)$ between time series of monthly data for each pair of samples. We first calculated synchrony of site pairs along the main channel of the river corridor. We examined whether nearby site pairs were more synchronous than site pairs separated by greater distances. We also examined synchrony across the lateral river-floodplain transect. Across this transect the nine sampling sites were arranged from highest sodium concentrations toward lowest concentrations representing a lateral groundwaterriver gradient. The mean Pearson correlation of all variables among all site pairs was plotted against rank order (spatial proximity) of each site pair. For calculating the spatial proximity for each pair of sites, a ranking was assigned ' 1 ' if the two sites were adjacent, ' 2 ' if the pair was separated by one other site, and so on (see Kling et al. 2000).

Mixing model-A two end member mixing model based on measured concentrations of sodium $(\mathrm{Na})$ was used to determine whether the floodplain was acting as a source or sink of nutrients and organic matter. Streamflow at the outlet of the floodplain (site 8) was assumed to be derived primarily from two sources of water, (1) glacial water (subglacial and englacial origin) entering the floodplain at site 3 and (2) hillslope groundwater. Inputs of snowmelt water to the floodplain were implicitly considered by the model because they occurred either via groundwater flow paths or surface flow paths at site 3. Because there was little overland flow due to the presence of thick morainic and fluvioglacial deposits in the Val Roseg catchment, snowmelt water on nonglaciated slopes of the catchment contributed to the recharge of hillslope groundwater and followed subsurface flow paths prior to entering the floodplain (Malard et al. 1999). Snowmelt water originating from the snowpack on the main glaciers entered the floodplain via surface flow paths at site 3. Sodium was considered a conservative hydrological tracer for this glacial river because its concentrations showed a large and consistent difference between glacial water and groundwater (Malard et al. 1999). Sodium is thought to be more conservative than $\mathrm{SiO}_{2}$, which can be taken up by algae. 
Nutrients and OM in a glacial river

Table 1. Characterization of the four hydrological phases (see text for further explanation). Surface connectivity: relative proportion (\%) of the channel network length having an upstream connection with the main river channel. Turbidity, specific conductance, and temperature are from site 8 in the main channel.

\begin{tabular}{|c|c|c|c|c|}
\hline & $\begin{array}{l}\text { Low water } \\
\text { season }\end{array}$ & $\begin{array}{l}\text { Expansion } \\
\text { season }\end{array}$ & $\begin{array}{c}\text { Glacial ablation } \\
\text { season }\end{array}$ & $\begin{array}{c}\text { Contraction } \\
\text { season }\end{array}$ \\
\hline Season (months) & Jan-Mar & Apr-Jun & Jul-Sep & Oct-Dec \\
\hline Discharge (biweekly average; $\mathrm{m}^{3} \mathrm{~s}^{-1}$ ) & $0.13-0.23$ & $0.3-7.0$ & $3.1-10.4$ & $0.3-2.0$ \\
\hline Surface connectivity $(\%)$ & $5-6$ & $5-31$ & $44-45$ & $5-31$ \\
\hline Turbidity (Nephelometric Turbidity Units) & $0.7-4.5$ & $3.0-48$ & $85-164$ & $2-54$ \\
\hline Specific conductance $\left(\mu \mathrm{S} \mathrm{cm} \mathrm{cm}^{-1}\right)$ & $84-88$ & $61-91$ & $35-47$ & $40-77$ \\
\hline
\end{tabular}

Elevated $\mathrm{Na}$ and $\mathrm{SiO}_{2}$ concentrations in hillslope groundwater of the Val Roseg catchment originate from dissolution of plagioclase that is enhanced by long flow paths through the weathered rock materials of the valley slopes (Malard et al. 1999). Hillslope groundwater may also acquire elevated $\mathrm{Na}$ and $\mathrm{SiO}_{2}$ concentrations from soils. In contrast, weathering of calcite dominated during the rapid movement of icemelt water through freshly exposed rock material deposited below the glacier. Consequently, although glacial water, in particular subglacial water, could be enriched in calcium, it always had low $\mathrm{Na}$ concentrations. Concentrations of $\mathrm{Na}$ at site 3 averaged $0.53 \pm 0.22 \mathrm{mg} \mathrm{L}^{-1}$ (range: $0.14 \mathrm{mg} \mathrm{L}^{-1}$ to $0.70 \mathrm{mg} \mathrm{L}^{-1}, n=12$; Malard et al. 1999). Samples for the groundwater component were taken from the upstream end of channel H3, a major springbrook fed by hillslope groundwater. Samples from this channel had an average Na concentration of $1.6 \pm 0.1 \mathrm{mg} \mathrm{L}^{-1}$ (range: $1.4 \mathrm{mg} \mathrm{L}^{-1}$ to 1.8 $\mathrm{mg} \mathrm{L}^{-1}, n=12$ ). Concentrations of $\mathrm{Na}$ at the outlet of the floodplain were measured from samples collected at site 8 . The relative contribution of glacial water to the floodplain discharge was calculated using the following formula (Williams et al. 1993):

$$
f_{1}=\left(C_{s}-C_{2}\right) /\left(C_{1}-C_{2}\right)
$$

where $f_{1}$ is the fraction of stream flow entering at the upstream end of the floodplain (site 3, englacial and subglacial water), and $C_{1}, C_{2}$, and $C_{s}$ represent the Na concentrations of glacial water (site 3), groundwater (site $\mathrm{H} 2$ ), and surface water at the floodplain outlet (site 8), respectively. For testing the validity of the mixing model, we checked that measured/predicted ratios of parameters that were expected to be conservative (i.e., specific conductance, TIC, calcium, and magnesium) were statistically equaled to 1 . In order to assess the role of the floodplain as a sink or source, predicted concentrations of nutrients and organic matter (simple mixing of water sources) were plotted against measured concentrations. Predicted versus measured concentrations were compared using both a paired $t$-test and a Wilcoxon paired test.

Export rates-For estimating export rates, diel cycles were determined by measuring nutrient and organic matter concentrations every three hours from 0600 to $2400 \mathrm{~h}$ at the downstream end of the floodplain (monthly interval). During these measurements discharge varied between 0.13 and 12.6 $\mathrm{m}^{3} \mathrm{~s}^{-1}$ with diel amplitudes ranging from 1.8 to $4.9 \mathrm{~m}^{3} \mathrm{~s}^{-1}$ (June to September).
We identified discharge-concentration functions $c=f(Q)$ by linear regression (77 data points for each parameter). For dissolved nitrogen species we identified four functions and for suspended solids and particulate phosphorous two functions to account for the distinct seasonal patterns of these parameters (seasons correspond to Table 1). We calculated annual export rates $F_{a}$ as

$$
F_{a}=\int_{t=0}^{t=365} Q(t) f(Q(t)) d t
$$

$Q(t)$ was the continuous discharge record of the gauging station at the end of the catchment (continuous measurements by the Swiss National Hydrological and Geological Survey). We are aware that a discrete sampling design will underestimate total export rates, in particular of variables that are strongly linked with discharge. Hence, rates have to be considered as minimum values for this glacial catchment.

\section{Results}

Hydrology - The Roseg River showed a distinct seasonal flow regime typical for a glacial melt dominated river (Fig. 2a). Discharge at the outlet of the floodplain (site 8) was primarily from two sources of water: (a) surface (englacial and subglacial origin) water entering the floodplain at site 3 and (b) hillslope groundwater. The relative contribution of hillslope groundwater to total floodplain discharge varied seasonally from $<10 \%$ during the main ablation period in summer to $>70 \%$ during low winter flow. Total channel network length increased from $5.8 \mathrm{~km}$ in winter to $21.7 \mathrm{~km}$ in summer (Fig. 2b). The relative contribution of groundwater to total discharge also increased downstream (e.g., in July from $1.2 \%$ at site 7 to $18 \%$ at site 10 ). A sharp increase of groundwater contribution at site $8(3.7 \mathrm{~km}$ downstream from the glacier front) indicated additional upwelling of groundwater at the downstream end of the floodplain (Fig. 2c).

Hydrologically, four periods could be separated (Fig. 2a, Table 1). A low water period in winter was characterized by the dominance of groundwater flow and resulting constant environmental conditions (low uniform flow, short channel network length, low temperature, low turbidity and high specific conductance). An expansion period in spring was linked to the recharge of aquifers with snowmelt water. Channel network length and surface connectivity (proportion of the total channel network length that had an upstream 


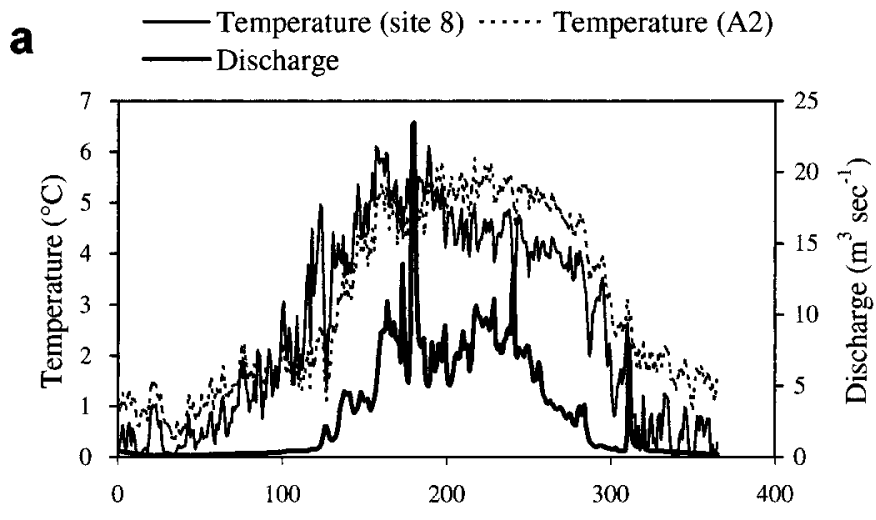

b

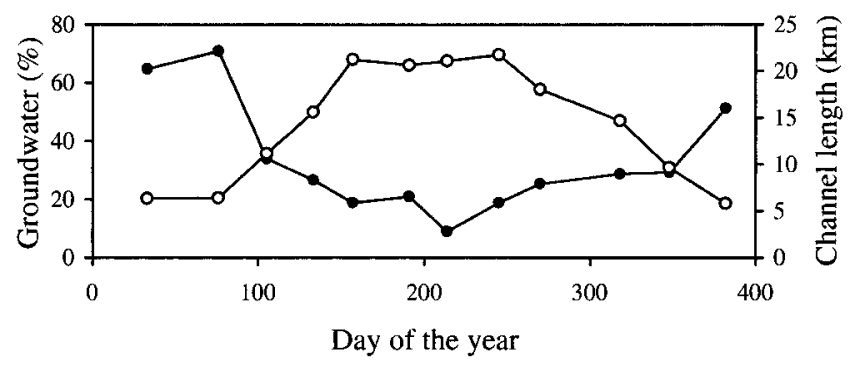

c

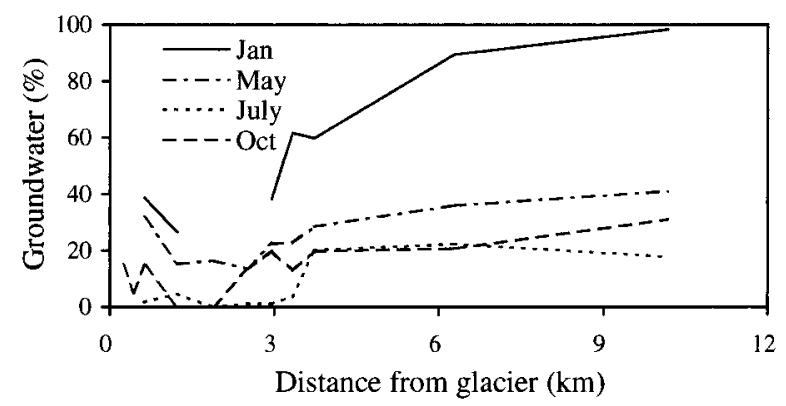

Fig. 2. (a) Annual discharge of the Roseg River in 1997 and surface water temperature (daily average) in the main channel (site 8) and a groundwater channel (site A2). (b) Relative contribution of groundwater (percentage) to total river-floodplain discharge (filled circles) and seasonal development of floodplain channel network length ( $\mathrm{km}$, open circles). The relative contribution of groundwater was calculated using a two end member mixing model based on differences in $\mathrm{Na}$ concentrations measured at sites $3, \mathrm{H} 2$, and 8 , respectively. (c) Relative contribution of hillslope groundwater (percentage) to discharge along the main stem of the Roseg River in January, May, July, and October 1997 representing the four main hydrological phases.

surface connection with the main channel) increased rapidly during the expansion phase. During the glacial ablation period in summer, overflow of the main channel water resulted in maximum channel network length and surface connectivity. During glacial ablation most channels were characterized by high turbidity and low specific conductance values. In autumn the contraction cycle followed more or less the reversed pattern of the expansion cycle, although different hydrological processes caused a decrease of channel network length (see below).
Table 2. Nutrient and organic matter composition (mean \pm SD) of different water sources in the Val Roseg flood plain using examples from representative sites (snow, 17 April 1997; glacial melt water, site 3, July to September 1997; hillslope ground water, site H2, July to September 1997). Nd: not detectable. $n=3$ per water source.

\begin{tabular}{lccc}
\hline \hline \multicolumn{1}{c}{ Variable } & Snow & $\begin{array}{c}\text { Glacial } \\
\text { melt water }\end{array}$ & $\begin{array}{c}\text { Hillslope } \\
\text { ground water }\end{array}$ \\
\hline $\mathrm{ISS}\left(\mathrm{mg} \mathrm{L}^{-1}\right)$ & no data & $60 \pm 25$ & $17 \pm 22$ \\
$\mathrm{POM}\left(\mathrm{mg} \mathrm{L}^{-1}\right)$ & no data & $4 \pm 1$ & $2 \pm 1$ \\
$\mathrm{NH}_{4}\left(\mu \mathrm{g} \mathrm{L}^{-1}\right)$ & $55 \pm 10$ & $15 \pm 3$ & $2 \pm 2$ \\
$\mathrm{NO}_{3}\left(\mu \mathrm{g} \mathrm{L}^{-1}\right)$ & $148 \pm 17$ & $227 \pm 24$ & $180 \pm 25$ \\
$\mathrm{DON}\left(\mu \mathrm{g} \mathrm{L}^{-1}\right)$ & $230 \pm 64$ & $32 \pm 23$ & $81 \pm 54$ \\
$\mathrm{PN}\left(\mu \mathrm{g} \mathrm{L}^{-1}\right)$ & $71 \pm 16$ & $20 \pm 8$ & $22 \pm 12$ \\
$\mathrm{SRP}\left(\mu \mathrm{g} \mathrm{L}^{-1}\right)$ & $10 \pm 5$ & $2 \pm 0$ & $0.3 \pm 0.5$ \\
$\mathrm{NRP}\left(\mu \mathrm{g} \mathrm{L}^{-1}\right)$ & $8 \pm 2$ & $5 \pm 1$ & $3 \pm 2$ \\
$\mathrm{PP}\left(\mu \mathrm{g} \mathrm{L}^{-1}\right)$ & $12 \pm 5$ & $97 \pm 40$ & $4 \pm 2$ \\
$\mathrm{DOC}\left(\mathrm{mg} \mathrm{L}^{-1}\right)$ & $1.1 \pm 0.1$ & $0.3 \pm 0.2$ & $0.9 \pm 0.6$ \\
$\mathrm{POC}\left(\mathrm{mg} \mathrm{L}^{-1}\right)$ & $1.2 \pm 0.1$ & $0.3 \pm 0.2$ & $0.2 \pm 0$ \\
$\mathrm{SiO}\left(\mathrm{mg} \mathrm{L}^{-1}\right)$ & $0.1 \pm 0.1$ & $1.2 \pm 0.2$ & $5.1 \pm 0.3$ \\
$\mathrm{Na}\left(\mathrm{mg} \mathrm{L}^{-1}\right)$ & $\mathrm{Nd}$ & $0.2 \pm 0.1$ & $1.6 \pm 0.1$ \\
\hline
\end{tabular}

Seasonal dynamics of nutrients and organic matter-The nutrient and organic matter composition of snowmelt water, bulk melt water from the glaciers, and hillslope groundwater is listed in Table 2. Depth-integrated snow samples collected at the end of the accumulation period were enriched in POC, DOC, and most nitrogen species. Glacial melt water had elevated concentrations of $\mathrm{PP}$ and $\mathrm{NO}_{3}-\mathrm{N}$. Concentrations of $\mathrm{SiO}_{2}, \mathrm{Na}$, and DOC were distinctly higher in hillslope groundwater than in glacial water. There was a distinct seasonal sequence in concentration peaks of nutrient and organic matter (Fig. $3 \mathrm{a}-\mathrm{c}$ ). $\mathrm{SiO}_{2}$ and $\mathrm{DOC}$ peaked in winter; $\mathrm{NO}_{3}-\mathrm{N}$ peaked in early spring, followed by peaks in DON, $\mathrm{PP}$, ISS, $\mathrm{POM}$, and $\mathrm{NH}_{4}-\mathrm{N}$. Concentrations versus discharge revealed marked differences between expansion and contraction phases (Fig. 3d-f). Concentrations of $\mathrm{NO}_{3}-\mathrm{N}$ and DON were much higher during the expansion than during the contraction phase. PP and $\mathrm{NH}_{4}-\mathrm{N}$ exhibited a reverse pattern. Concentrations of $\mathrm{SiO}_{2}$ and $\mathrm{DOC}$ decreased with increasing discharge, with only minor differences between expansion and contraction phases.

Lateral and longitudinal patterns of nutrients and organic matter $-\mathrm{SiO}_{2}, \mathrm{DOC}$, and $\mathrm{NO}_{3}-\mathrm{N}$ exhibited trends of increasing concentrations from connected (surface water fed) toward disconnected channels (hillslope groundwater fed), whereas concentrations of PP decreased (Table 3). $\mathrm{SiO}_{2}$ concentrations were up to 3.8 times higher in hillslope groundwater-fed channels compared to surface-connected channels. Concentrations of TP, TN, and TOC were significantly different among seasons, and, except for TOC, among channel types. There were significant interactions between channel type and season, except for TOC, indicating that seasonal patterns varied as a function of channel type (Table 4). Post hoc comparisons showed that TOC concentrations were significantly higher in disconnected channels compared to subsurface-connected ones; TN was significantly higher in disconnected channels, whereas TP was highest in connected 

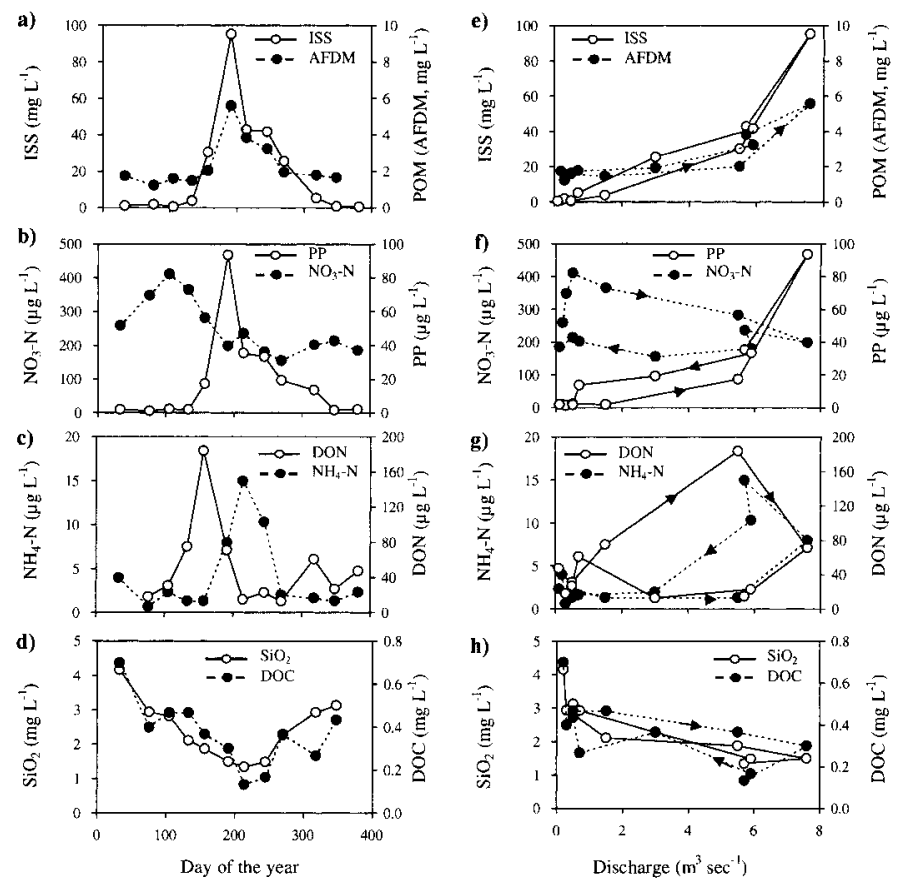

Fig. 3. Seasonal dynamics of (a) inorganic suspended solids (ISS) and particulate organic matter (POM, expressed as AFDM), (b) Nitrate- $\mathrm{N}\left(\mathrm{NO}_{3}-\mathrm{N}\right)$ and particulate phosphorous (PP), (c) ammonium $\left(\mathrm{NH}_{4}-\mathrm{N}\right)$ and dissolved organic nitrogen (DON), (d) silicate $\left(\mathrm{SiO}_{2}\right)$ and dissolved organic carbon (DOC). (e-h) Relationship between discharge and concentrations of the above variables. Arrows pointing to the right indicate the expansion phase, whereas arrows pointing left indicate the contraction phase. All samples were taken between 0600 and $0900 \mathrm{~h}$ at the lower end of the floodplain (site 8).

channels. Seasonally, TP concentrations were similar during the expansion and contraction periods, and TN concentrations were similar during the main ablation and the contraction periods.

Downstream patterns of nutrients and organic matter were primarily disrupted by the confluence with the proglacial lake outlet and by the knickpoint at the downstream end of the floodplain. The lake outlet led to either an increase or a decrease of concentrations, depending on the individual variable and the season. For example, $\mathrm{NO}_{3}-\mathrm{N}$ concentrations decreased downstream of the lake outlet, whereas DOC concentrations increased, at least in July and October. The floodplain itself had major influences on the longitudinal pattern of ISS and PP (Fig. 4). In the constrained section downstream of the floodplain, particulate parameters and $\mathrm{NO}_{3}-\mathrm{N}$ remained relatively constant. $\mathrm{SiO}_{2}$ and $\mathrm{DOC}$, however, increased in March and October from site 8 to site 10.

The average synchrony for all variables was $0.66 \pm 0.15$ for the longitudinal transect and $0.37 \pm 0.16$ for the lateral transect. These averages were taken across all pairs of sites along both transects. Longitudinally, synchrony of variables ranged from 0.28 for PN to 0.95 for specific conductance. Six out of the 14 variables exhibited a significant synchrony across most sites. Laterally, synchrony ranged from 0.10 for $\mathrm{NH}_{4}-\mathrm{N}$ to 0.87 for DON. DON and $\mathrm{NO}_{3}-\mathrm{N}$ were the only variables that were in average significantly correlated across
Table 3. Average concentrations of selected variables in surfaceconnected, subsurface-connected (seepage-fed), and disconnected (hillslope-groundwater fed) floodplain channels during the four hydrological seasons ( $n=9$ per channel type and season).

\begin{tabular}{llccc}
\hline \hline & \multicolumn{1}{c}{ Period } & $\begin{array}{c}\text { Surface- } \\
\text { connected }\end{array}$ & $\begin{array}{c}\text { Subsurface- } \\
\text { connected }\end{array}$ & Disconnected \\
\hline $\mathrm{SiO}_{2}$ & Low water & 3.7 & 2.6 & 5.7 \\
$\left(\mathrm{mg} \mathrm{L}^{-1}\right)$ & Expansion & 2.6 & 2.7 & 5.9 \\
& Glacial ablation & 1.6 & 2.7 & 6.1 \\
& Contraction & 2.2 & 2.2 & 6.3 \\
$\mathrm{DOC}$ & Low water & 0.4 & 0.4 & 0.5 \\
$\left(\mathrm{mg} \mathrm{L}^{-1}\right)$ & Expansion & 0.4 & 0.3 & 0.5 \\
& Glacial ablation & 0.2 & 0.2 & 0.6 \\
& Contraction & 0.4 & 0.5 & 0.5 \\
$\left.\mathrm{POC}_{(m g ~ L}-1\right)$ & Low water & 0.17 & 0.17 & 0.11 \\
& Expansion & 0.13 & 0.11 & 0.10 \\
& Glacial ablation & 0.26 & 0.09 & 0.12 \\
$\mathrm{NO}_{3}-\mathrm{N}$ & Contraction & 0.17 & 0.16 & 0.15 \\
$\left(\mu \mathrm{g} \mathrm{L}^{-1}\right)$ & Low water & 265 & 301 & 263 \\
& Expansion & 353 & 393 & 432 \\
& Glacial ablation & 205 & 173 & 244 \\
$\mathrm{PP}$ & Contraction & 190 & 191 & 228 \\
$\left(\mu \mathrm{g} \mathrm{L}^{-1}\right)$ & Low water & 1.8 & 1.1 & 1.6 \\
& Expansion & 7.2 & 3.4 & 2.8 \\
& Glacial ablation & 54.0 & 7.4 & 3.8 \\
& Contraction & 11.5 & 4.1 & 5.3 \\
\hline
\end{tabular}

all sampling sites (Table 5). Synchrony decreased with distance. Sites close to one another had higher synchrony values than sites more separated in space (longitudinal transect) or sites arranged along the lateral groundwater-surface water gradient. Within the floodplain, synchrony was much lower among groundwater sites $(0.35 \pm 0.12)$ than among subsurface-connected $(0.52 \pm 0.02)$ or surface-connected waters $(0.79 \pm 0.05)$.

Floodplain retention-Measured/predicted ratios of parameters that were expected to be conservative (i.e., specific conductance, total inorganic carbon, calcium, and magne-

Table 4. Summary of two-way ANOVA comparing chemical variables among sampling seasons and study sites (connectivity type).

\begin{tabular}{lrrrr}
\hline \hline & $d f$ & MS & $F$ & \multicolumn{1}{c}{$P$} \\
\hline TN & 2 & 0.045 & 5.29 & 0.007 \\
$\quad$ Type & 3 & 0.521 & 61.78 & $<0.001$ \\
Season & 6 & 0.020 & 2.40 & 0.037 \\
Season $\times$ type & 90 & 0.008 & & \\
Error & & & & \\
TP & 2 & 0.979 & 16.42 & $<0.001$ \\
Type & 3 & 1.513 & 25.37 & $<0.001$ \\
Season & 6 & 0.373 & 6.26 & $<0.001$ \\
Season $\times$ type & 90 & 0.060 & & \\
Error & & & & \\
TOC & 2 & 0.020 & 7.33 & 0.15 \\
$\quad$ Type & 3 & 0.051 & 1.84 & 0.01 \\
$\quad$ Season & 6 & 0.005 & 1.90 & 0.09 \\
Season $\times$ type & 90 & 0.003 & & \\
Error & & & & \\
\hline
\end{tabular}



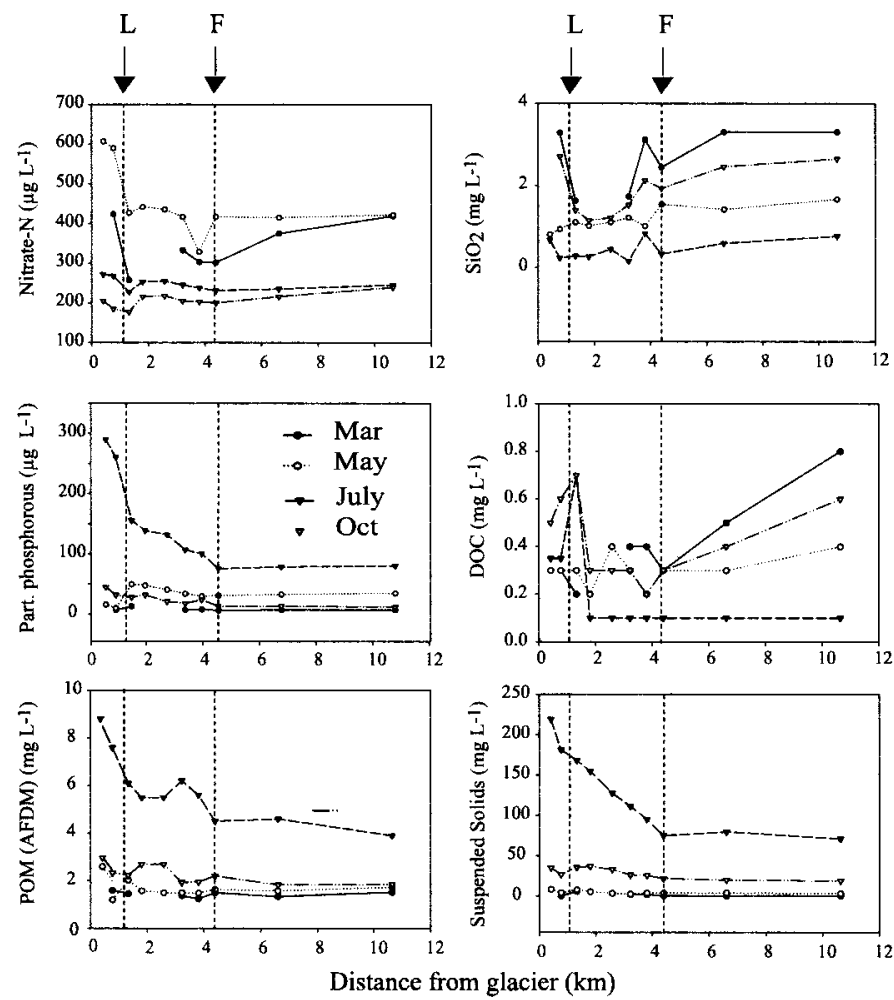

Fig. 4. Longitudinal patterns of selected parameters at main channel sites in March, May, July, and October 1997, representing four major hydrological periods (see Table 1). L is lake inflow; $\mathrm{F}$ is knickpoint at the lower end of the floodplain. In March, several sites in the upper part of the floodplain lacked surface water.

sium) were not significantly different from 1 . Comparisons of measured concentrations and concentrations predicted by the two end member mixing model indicated that the floodplain served as a major sink for ISS and PP (sedimentation processes during the main ablation period) and as a minor sink for dissolved nitrogen $\left(\mathrm{NO}_{3}-\mathrm{N}\right.$ and DON) (Fig. 5). For these parameters, measured concentrations were significantly lower than values predicted from the mixing model (paired $t$-test and Wilcoxon paired test). For all other parameters, including DOC and POC, no significant differences $(p>$ 0.05 ) between measured and predicted concentrations were found. The floodplain did not serve as a source for any of the parameters.

Export rates of nutrients and organic matter-Concentrations of particulate parameters (excluding PN) and SRP were positively related to discharge; DOC and TIC were negatively related to discharge; $\mathrm{PN}, \mathrm{DON}$, and $\mathrm{NO}_{3}-\mathrm{N}$ were unrelated to discharge. Concentrations of PP and POC were significantly related to concentrations of suspended solids $\left(r^{2}\right.$ $=0.90$ and 0.64 , respectively). Suspended solids comprised $0.1 \%$ and $1.6 \%$ of PP and POC, respectively.

The annual export rates of DOC and POC were $24 \mathrm{t}$ and $27 \mathrm{t}$, respectively. The annual export rate of TN was $28.4 \mathrm{t}$ $\mathrm{yr}^{-1} . \mathrm{NO}_{3}, \mathrm{DON}, \mathrm{NH}_{4}$, and particulate nitrogen contributed $77.5 \%, 16.2 \%, 1.7 \%$, and $4.6 \%$, respectively, to total nitrogen flux. Export rate for SRP was as low as $0.2 \mathrm{t} \mathrm{yr}^{-1} \mathrm{com}-$
Table 5. Average synchrony values (proportion of strong correlations that are statistically significant) as determined by Pearson correlation for each variable across all sampling sites along the lateral and the longitudinal gradients (defined in the text). Bold values are statistically significant at the $p<0.05$ level.

\begin{tabular}{|c|c|c|c|c|}
\hline \multirow[b]{2}{*}{ Variable } & \multicolumn{2}{|c|}{$\begin{array}{l}\text { Longitudinal } \\
\text { gradient }\end{array}$} & \multicolumn{2}{|c|}{$\begin{array}{l}\text { Lateral } \\
\text { gradient }\end{array}$} \\
\hline & $\begin{array}{l}\text { Syn- } \\
\text { chrony }\end{array}$ & $\begin{array}{c}\text { Strong } \\
\text { correlations } \\
(\%)\end{array}$ & $\begin{array}{l}\text { Syn- } \\
\text { chrony }\end{array}$ & $\begin{array}{c}\text { Strong } \\
\text { correlations } \\
(\%)\end{array}$ \\
\hline Specific conductance & 0.95 & 100 & 0.60 & 42 \\
\hline POM (AFDM) & 0.91 & 96 & 0.26 & 8 \\
\hline Suspended solids (ISS) & 0.89 & 71 & 0.33 & 28 \\
\hline $\mathrm{SiO}_{2}$ & 0.89 & 89 & 0.16 & 8 \\
\hline $\mathrm{NO}_{3}-\mathrm{N}$ & 0.88 & 80 & $\mathbf{0 . 8 0}$ & 69 \\
\hline $\mathrm{Na}$ & 0.84 & 73 & 0.28 & 6 \\
\hline Particulate P & 0.69 & 52 & 0.19 & 8 \\
\hline DON & 0.63 & 32 & 0.87 & 86 \\
\hline POC & 0.59 & 25 & 0.13 & 0 \\
\hline SRP & 0.56 & 25 & 0.40 & 11 \\
\hline DOC & 0.46 & 32 & 0.46 & 17 \\
\hline TOC & 0.33 & 16 & 0.41 & 6 \\
\hline $\mathrm{NH}_{4}-\mathrm{N}$ & 0.32 & 25 & 0.10 & 11 \\
\hline PN & 0.28 & 0 & 0.14 & 6 \\
\hline
\end{tabular}

pared to an export of PP of $28 \mathrm{t} \mathrm{yr}^{-1}$. Particulate phosphorous constituted $98 \%$ of the total phosphorous flux from the catchment. Annual export of suspended solids was as high as $28,450 \mathrm{t} \mathrm{yr}^{-1}$, corresponding to an area-specific rate of $4.2 \mathrm{t} \mathrm{ha}^{-1} \mathrm{yr}^{-1}$ (Table 6).

\section{Discussion}

Hydrology-The Val Roseg river-floodplain system is characterized by distinct expansion and contraction periods that are associated with major changes in channel network length, solute concentrations, and temperature. For example, the entire system shifts from a groundwater-dominated system in winter to a surface-dominated system in summer (Fig. 2b; Malard et al. 1999, 2000). Change in ecosystem size is a fundamental property of floodplains, although rarely quantified (Tockner et al. 2000). In the Val Roseg, several water sources contribute to the expansion of the channel network, including groundwaters, snowmelt, and glacial water. Snowmelt (May and June) and meltwater from the glaciers are responsible for the expansion of the channel network. Seasonal shifts in water sources and flow pathways create complex spatial and temporal patterns of nutrient and organic matter. These patterns are clearly driven by hydrological processes within the catchment-floodplain complex (Table 1).

Seasonal dynamics of nutrients and organic matter-Inputs of water from different sources modify seasonal patterns of nutrients and organic matter. Groundwater dominance in winter is associated with high DOC, silicate, and sodium concentrations in all water bodies. Silica concentrations in hillslope groundwater originate from dissolution of plagioclase during longer groundwater flow paths in weathered rock materials of the valley slopes. Hillslope groundwater 

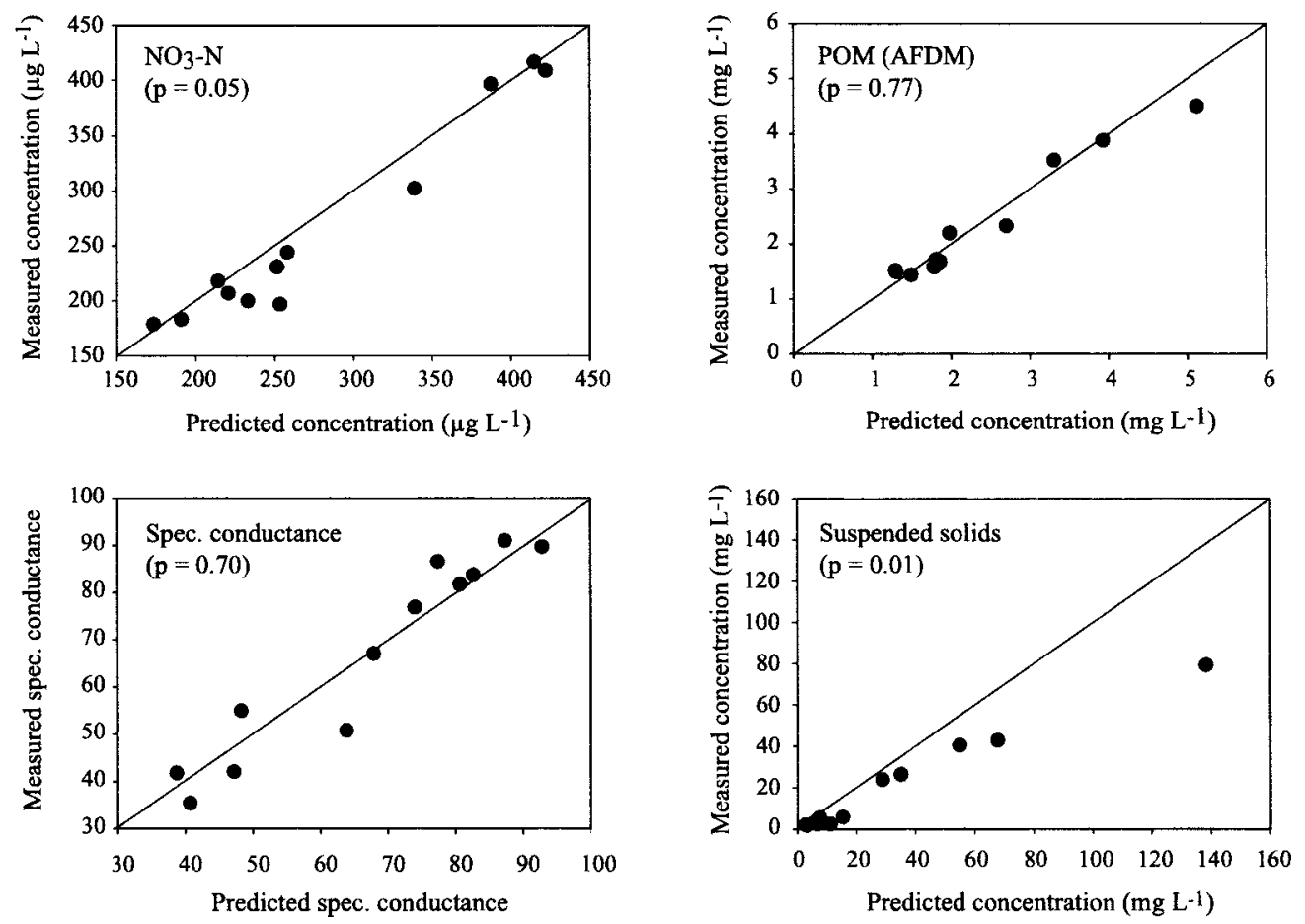

Fig. 5. Measured concentrations versus concentrations predicted from a two end member mixing model at the downstream end of the floodplain (site 8) for nitrate-N, POM, specific conductance, and inorganic suspended solids $(n=12)$. Lines indicate $1: 1$ equivalence relationship.

may also acquire elevated $\mathrm{SiO}_{2}$ concentrations from soils (Malard et al. 1999). Elevated DOC concentrations measured in groundwater and disconnected channels and during groundwater-dominated base flow strongly suggested that groundwater was a source of dissolved organic matter to the river. However, the production site of DOC in the Roseg catchment warrants further investigations. Several studies have shown DOC in groundwater to be generated during shallow subsurface flow paths through soils (e.g., Kaplan and Newbold 2000). Annual DOC concentrations average about $0.5 \mathrm{mg} \mathrm{L}^{-1}$, which is much below the average values

Table 6. Total and area-specific annual export rates for the Val Roseg catchment.

\begin{tabular}{|c|c|c|}
\hline Variable & $\begin{array}{l}\text { Annual } \\
\text { export } \\
\left(\mathrm{t} \mathrm{yr}^{-1}\right)\end{array}$ & $\begin{array}{c}\text { Specific } \\
\text { export } \\
\left(\mathrm{kg} \mathrm{ha}^{-1}\right. \\
\left.\mathrm{yr}^{-1}\right)\end{array}$ \\
\hline Suspended solids (ISS) & 28,450 & 4200 \\
\hline Nitrate-nitrogen $\left(\mathrm{NO}_{3}-\mathrm{N}\right)$ & 22 & 3.3 \\
\hline Ammonium-N $\left(\mathrm{NH}_{4}-\mathrm{N}\right)$ & 0.5 & 0.07 \\
\hline Dissolved organic nitrogen (DON) & 4.6 & 0.7 \\
\hline Particulate nitrogen $(\mathrm{PN})$ & 1.3 & 0.2 \\
\hline Soluble reactive phosphorous (SRP) & 0.2 & 0.03 \\
\hline Soluble nonreactive phosphorous (NRP) & 0.4 & 0.05 \\
\hline Particulate phosphorous (PP) & 28 & 4.2 \\
\hline Particulate organic matter (POM) & 444 & 66 \\
\hline Particulate organic carbon (POC) & 27 & 4.0 \\
\hline Dissolved organic carbon (DOC) & 24 & 3.6 \\
\hline Total inorganic carbon (TIC) & 392 & 58 \\
\hline
\end{tabular}

reported for small streams in arctic tundra and alpine environments (Thurman 1985). In summer, concentrations can be as low as $0.1 \mathrm{mg} \mathrm{L}^{-1}$. Exceptionally high DOC concentrations in surface water of the Roseg floodplain (i.e., 3.4 $\mathrm{mg} \mathrm{L}^{-1}$ ) were measured once during a rainfall event that caused leaching of soils (Tockner et al. 1997). Increasing DOC concentrations during groundwater-dominated base flow may also reflect in-stream production by algae, although this process was not evidenced by our mixing model.

The glacier is the primary source for POM (expressed as AFDM) and POC in the Val Roseg river floodplain as shown by seasonal peaks in midsummer (see Fig. 3). The glacier is expected to accumulate POM that is primarily blown in by aeolian drift (e.g., Teeri and Barrett 1977) and then released during the main melting period. Allochthonous inputs of POM from the adjacent terrestrial area play a minor role in this glacial floodplain. Zah et al. (in press), who measured inputs of organic matter along the Val Roseg River, reported total annual inputs of POM ranging from $1.1 \mathrm{~g} \mathrm{AFDM} \mathrm{m}^{-2}$ $\mathrm{yr}^{-1}$ close to the glacier to $10 \mathrm{~g}^{\mathrm{AFDM} \mathrm{m}} \mathrm{m}^{-2} \mathrm{yr}^{-1}$ in the floodplain section and finally to a maximum of $34 \mathrm{~g}$ AFDM $\mathrm{m}^{-2} \mathrm{yr}^{-1}$ in the lower forested section close to the river mouth. These input rates are about 1 to 2 orders of magnitude lower than those reported for forested headwater streams (e.g., Weigelhofer and Waringer 1994).

As in many other mountain areas (e.g., Charles 1991), melting of the snowpack resulted in a pulse of nitrates in the river. High concentrations of total nitrogen (primarily DON) together with silica and POC in snow samples collected in April are likely to originate from dry deposition, especially 
during the end of the snow accumulation period when the lower tropospheric convection extends upward to glacier altitudes (Nickus et al. 1997). The importance of aeolian particulates for both ionic and particulate content of the snowpack has been emphasized by several studies (Williams and Melack 1989; Nickus et al. 1997; references herein). According to the maps of atmospheric deposition for Switzerland, the deposition of nitrogen in the Val Roseg catchment is $10-15 \mathrm{~kg} \mathrm{~N} \mathrm{ha}^{-1} \mathrm{yr}^{-1}$ (Rihm 1996). A prolonged gradual decline of $\mathrm{NO}_{3}-\mathrm{N}$ in late spring (over more than two months, cf. Fig. 3) reflects the spatiotemporal heterogeneity of snowmelt within the catchment (e.g., an altitude range $>2000 \mathrm{~m}$ ) and probably the temporary storage of $\mathrm{NO}_{3}-\mathrm{N}$ rich waters beneath the glacier. In other high alpine systems, nitrate pulses occur for only a few days to a few weeks (e.g., Williams and Melack 1989). Below the Haut Glacier d'Arolla, Switzerland, a complete depletion of $\mathrm{NO}_{3}-\mathrm{N}$ was measured during the main ablation period, probably as a result of microbial activities (Tranter et al. 1994). In the Val Roseg floodplain, maximum differences in concentrations during the year were about 2.5 times, probably reflecting permanent groundwater input that is likely to attenuate seasonal variation in nitrate concentration (cf. Fig. 3, Table 3). Gurnell and Fenn (1985) also have shown that solute concentrations in proglacial floodplains increase due to additional inputs of groundwater.

In the Val Roseg glacial system, DON and $\mathrm{NH}_{4}-\mathrm{N}$ represent a high proportion of TDN (48\% DON) in the snowpack; $\mathrm{NO}_{3}-\mathrm{N}$, however, was the dominant form of nitrogen $(87 \%)$ in streamwater. The source of high $\mathrm{NO}_{3}-\mathrm{N}$ concentrations during spring runoff is expected to be from (1) oxidation of $\mathrm{NH}_{4}$ released from snowpack to $\mathrm{NO}_{3}-\mathrm{N}$ and (2) from mineralization processes of DON in soils and subsequent transport by meltwater percolating through the soil (see Williams and Melack 1989). More recently, Brooks and Williams (1999) provided an overview on N cycling in seasonally snow covered alpine catchments (Colorado Front Range). These authors found that the duration of winter snow cover and the subsequent heterotrophic activity in soils played a predominant role on the variability of $\mathrm{N}$ export. For catchments in the Sierra Nevada (California), Sickman et al. (2001) found that the timing of snowmelt runoff had a large effect on nitrate pulses. Isotopic analyses suggested that the majority of the pulse was not from the snowpack, but rather from catchment soils. Labile $\mathrm{N}$ pools in soils were increasingly stocked during years of high snowfall. Although DON is a major component in surface water nitrogen (up to $50 \%$ of TDN in the Val Roseg catchment), few data are available about its role in streams. In a pilot study, Howard-Williams et al. (1989) recorded high DON concentrations $(>100 \mu \mathrm{g}$ $\mathrm{L}^{-1}$ ) for glacial meltwater streams in Antarctica. Most of this DON was urea-N that was used by thick algal mats in the stream. In temperate headwater streams, DON constituted between $17 \%$ and $95 \%$ of the total dissolved nitrogen flux (McHale et al. 2000 and references herein). This is considerably higher than the total annual export in the Val Roseg catchment $(16.2 \%)$.

High concentrations of particulate phosphorus in glacial water (in summer $>1 \mathrm{mg} \mathrm{g}^{-1}$ ) reflect the resuspension of glacial flour enriched in apatite during high-flow periods.
Glacial flour can be an important source of SRP (Bretschko 1966). Indeed, SRP concentrations peaked during the main ablation period in midsummer, although concentrations were always very low $\left(<3 \mu \mathrm{g} \mathrm{L}^{-1}\right)$. In the Val Roseg floodplain, experiments with nutrient diffusing substrata performed in spring 1997 suggested that phosphorous limited the accrual of benthic algae (U. Uehlinger and C.T. Robinson pers. comm.).

Longitudinal and lateral patterns of nutrients and organic matter-The balance between longitudinal transport from the catchment and lateral transport between the floodplain and the river determines organic matter and nutrient fluxes in a floodplain. In the Val Roseg floodplain, variation along the main channel differs between seasons and parameters. Longitudinal patterns of nutrients are modified by inputs of different water sources, in particular by the lake outlet and the upwelling of groundwater at the downstream end of the floodplain (see Fig. 4).

The average synchrony value of 0.66 along the main channel of the river is much higher than values reported for similar variables from other areas (Kling et al. 2000 and references therein). High synchrony is generated when sites respond similarly to a common driver. Our results illustrate that patterns of nutrients and organic matter are much more coherent over time along the main channel of the river than across a lateral river-floodplain gradient. A high synchrony in the main channel indicates catchment control (snowmelt, glacier ablation) on nutrients and organic matter dynamics. Laterally, a much lower synchrony results from the greater dominance of local hydrological and/or biogeochemical processes. Local processes within the floodplain, like exchange processes between individual water bodies and local groundwater upwelling, are superimposed on contributions from snowmelt, as demonstrated by high values of synchrony for nitrate-nitrogen and dissolved organic nitrogen. Lesack et al. (1998), who studied Mackenzie Delta lakes (Canadian Arctic), also reported a dominance of local processes in about one-third of their floodplain lakes. Low synchrony among groundwater sites and among subsurface-connected water bodies may partly result from a lack of seasonality of many parameters (Soranno et al. 1999). For example, specific conductance, turbidity (Malard et al. 1999), and DOC remain temporally more constant in disconnected channels compared to the main channel (cf. Table 3). On the other hand, disconnected (groundwater) channels exhibit a greater spatial variability than connected water bodies as demonstrated by Tockner et al. (1997).

Floodplain retention-The approach used to determine whether the floodplain was acting as a source or sink was based on the assumption that the two end member mixing model provided a reasonable estimate of concentrations expected at the floodplain outlet if only mixing processes were important. The fact that measured/predicted ratios of conservative variables (i.e., specific conductance, total inorganic carbon, calcium, and magnesium) did not significantly differ from 1 supported this assumption. Results of the mixing model also depended on our estimates of sodium, nutrient, and organic matter concentrations for each water source. Al- 
though we were relatively confident in our estimates of concentrations for glacial water because input to the floodplain occurred at a single point (site 3 ), we were less confident in our estimates of concentrations in hillslope groundwater (site H2) because inflows of groundwater occurred at multiple points within the floodplain. However, when we reiterated calculations using concentrations from other springbrooks fed by hillslope groundwater (i.e., sites $\mathrm{H} 2$ and $\mathrm{H} 3$ ), the dominant pattern in measured versus predicted concentrations remained the same, indicating little retention of nutrients and organic matter by the floodplain.

The glacial floodplain is primarily a transfer area for nutrients and organic matter originating from different catchment sources. Residence time of water is very short in the Val Roseg floodplain because all extant water bodies are lotic, irrespectively of discharge. In summer, transit time of surface water (based on tracer studies) through the floodplain is only about $40 \mathrm{~min}$ (U. Uehlinger pers. comm.). The floodplain, however, is a sink for ISS and PP as a result of sedimentation processes. Further, the floodplain serves as a minor sink for dissolved nitrogen. Uptake of nitrogen is restricted to autumn and early winter, the periods of highest benthic algae biomass (Uehlinger et al. 1998; cf. Fig. 5). In general, biologically mediated transformations typical for most floodplains (e.g. OM retention, nutrient cycling; see Robertson et al. 1999) are of low importance and do not affect concentrations of nutrients in a detectable way. Although biological transformations are expected to occur in groundwater channels, the contribution of groundwater channels to total floodplain discharge is very low during the main ablation period. Therefore, fluxes of most nutrients and organic matter within the floodplain can be explained by mixing processes of surface and groundwater. Similarly, in many floodplains the combination of varying inputs from rivers and local basins result in large seasonal fluctuations in the nutrient composition. However, in contrast to the Val Roseg floodplain, where lentic water bodies are almost lacking, significant biological uptake of DIN and SRP occur in most temperate and tropical floodplains, such as the Amazon or the Danube (Forsberg et al. 1988; Lewis et al. 1990; Tockner et al. 1999).

The Val Roseg floodplain is not a source for nutrients or organic matter. Most floodplains, however, act as both sinks and sources depending on the annual hydrograph, floodplain topography, and loads of the river. Frequently, floodplains are net sinks for particulate matter and nutrients $\left(\mathrm{NO}_{3}-\mathrm{N}\right)$ but major sources for organic matter and SRP (e.g., Robertson et al. 1999; Tockner et al. 1999). The floodplain of the Val Roseg is small $\left(0.67 \mathrm{~km}^{2}\right)$, but it is relatively large in respect to average discharge $\left(2.8 \mathrm{~m}^{3} \mathrm{~s}^{-1}\right)$. A $5 \mathrm{~km}^{2}$ large floodplain along the Upper Danube (average discharge: $2000 \mathrm{~m}^{3} \mathrm{~s}^{-1}$ ) played, however, a major role in transforming organic matter and nutrients (Tockner et al. 1999). In conclusion, the Val Roseg glacial floodplain exhibits distinct differences from floodplains at lower elevations.

Export rates-Calculations of organic matter and nutrient export rates from high alpine streams are rare (e.g., Webster and Meyer 1997). In the Val Roseg catchment, the areaspecific export rate of DOC is among the lowest values re- ported for riverine systems. Hudon et al. (1996) summarized DOC export rates of 46 rivers draining the Precambrian Shield of southeast Canada, with specific loads $\left(\mathrm{kg} \mathrm{ha}^{-1} \mathrm{yr}^{-1}\right)$ ranging from 5.6 to 99 , compared to 3.6 in the present study. Much lower values are reported only for a tiny brook in Antarctica. There, McKnight and Tate (1997) calculated DOC and POC rates of 0.04 and $0.14 \mathrm{~kg} \mathrm{ha}^{-1} \mathrm{yr}^{-1}$, respectively; low rates resulted from the low average flow (0.02 $\mathrm{m}^{3} \mathrm{~s}^{-1}$ ) and a flow duration of only $62 \mathrm{~d}$ in a year. In most catchments, organic carbon is primarily exported in the form of DOC. Oswood et al. (1996) calculated annual export rates of total carbon ranging from 13 to $31 \mathrm{~kg} \mathrm{ha}^{-1} \mathrm{yr}^{-1}$ for a small arctic tundra stream, with $>95 \%$ being DOC. In the Val Roseg catchment, POC and DOC contribute about equally to total carbon flux since the glacier is the major source for POC (see above).

Losses of suspended solids from the Val Roseg catchment are much higher than from undisturbed temperate or tropical montane catchments (e.g., McDowell and Ashbury 1994). The relatively rapid retreat of the glaciers in the Val Roseg catchment has exposed large areas of easily erodable material. For the Batua glacier (Karakorum, Collins 1999), specific sediment yield is $60 \mathrm{t} \mathrm{ha}^{-1} \mathrm{yr}^{-1}$, an order-of-magnitude higher than in the Val Roseg. In the Val Roseg, export rates of POC and TP covary with suspended sediments. Export rates of $4 \mathrm{~kg}$ POC $\mathrm{ha}^{-1} \mathrm{yr}^{-1}$ are similar to small temperate forested rivers (e.g., Webster and Meyer 1997). Export rates of TP (4.3 $\left.\mathrm{kg} \mathrm{ha}^{-1} \mathrm{yr}^{-1}\right)$, however, are higher compared to most catchments (e.g., Meybeck 1982).

In the Val Roseg catchment, $\mathrm{NO}_{3}-\mathrm{N}$ yield is much higher than values reported from temperate headwater catchments in North America $\left(0-0.56 \mathrm{~kg} \mathrm{ha}^{-1} \mathrm{yr}^{-1}\right)$ and slightly higher than from small tropical catchments (average: $2.43 \mathrm{~kg} \mathrm{ha}^{-1} \mathrm{yr}^{-1}$, Lewis et al. 1999). Despite its remote location, Val Roseg receives high inputs of anthropogenic nitrogen, primarily from the Po drainage basin (northern part of Italy). Annual deposition of total nitrogen (reduced and oxidized forms) averaged $12 \mathrm{~kg} \mathrm{ha}^{-1} \mathrm{yr}^{-1}$ (Rihm 1996), which is five times above baseline deposition in minimally impacted systems (Lewis et al 1999 and references therein). $\mathrm{DON}, \mathrm{NH}_{4}-\mathrm{N}$, and $\mathrm{PN}$ yields are much lower compared to tropical and temperate streams, although controls on DON concentrations and flux are poorly understood (Lewis et al. 1999; McHale et al. 2000).

Conclusion-In the Val Roseg glacial floodplain, hydrology (sources and pathways of water) is the major determinant of spatiotemporal patterns of environmental conditions (e.g., turbidity) and the availability of individual resources such as organic matter and nutrients. Summer high flow is associated with high sediment loads, low DOC, and nutrient concentrations in most parts of the channel network. Therefore, glacial floodplains lack the "flood pulse advantage" (sensu Bayley 1991) typical for lowland floodplains. However, the Val Roseg floodplain moderates considerably the harsh conditions that normally characterize high alpine streams (Malard et al. 2000; U. Uehlinger unpubl. data). Benign environmental conditions occur primarily during expansion and contraction events, rather than during the main ablation period in summer (when most studies have been conducted). Hence, two periods, the expansion period in 
spring and the contraction period in early autumn, can be identified when nutrient supply, organic matter conditions, sediment load, and temperature seem to be favorable for many ecological processes (e.g., decomposition of POM) and biota (e.g., benthic invertebrates) within this generally harsh environment. Uehlinger et al. (1998) found similar periods of time during which an accrual of benthic algae was observed. Burgherr and Ward (in press) found highest taxa richness and invertebrate densities of benthic invertebrates in spring and late autumn, corresponding to the periods of favorable environmental conditions. Future investigations will concentrate on the implications of resource availability/ limitation on benthic invertebrates and stream metabolism in this glacial floodplain.

\section{References}

American Public Health Association. 1989. Standard methods for the examination of water and wastewater, 17th ed. APHA.

BAYLEY, P. B. 1991. The flood pulse advantage and the restoration of river-floodplain systems. Regul. Rivers 6: 75-86.

BretschKo, G. 1966. Untersuchungen zur Phosphatführung zentralalpiner Gletscherabflüsse. Arch. Hydrobiol. 62: 327-334.

Brooks, P. D., AND M. W. WiLliams. 1999. Snowpack controls on nitrogen cycling and export in seasonally snow-covered catchments. Hydrol. Process. 13: 2177-2190.

BURGHERR, P., AND J. V. WARD. In press. Longitudinal and seasonal distribution patterns of the benthic fauna of an alpine glacial stream (Val Roseg, Swiss Alps). Freshw. Biol.

Charles, D. F. 1991. Acidic deposition and aquatic ecosystems. Springer.

Collins, D. N. 1981. Seasonal variation of solute concentration in meltwater draining from an alpine glacier. Ann. Glaciol. 1: 1116.

-1999. Solute flux in meltwater draining from a glacierized basis in the Karakoram mountains. Hydrol. Process. 13: 30013015.

Downes, M. T. 1978. An improved hydrazine reduction method for the automated determination of low nitrate levels in freshwater. Water Res. 12: 673-675.

Ebina, L., T. Tsutsui, AND T. Shirai. 1983. Simultaneous determination of total nitrogen and total phosphorus in water using peroxodisulfate oxidation. Water Res. 17: 1721-1726.

Everett, K. R., G. M. Marion, AND D. L. Kane. 1989. Seasonal geochemistry of an arctic tundra drainage basin. Holarct. Ecol. 12: $279-289$.

Forsberg, B. R., A. H. Devol, J. E. Richey, L. A. Martinelli, AND H. DOS SANTOS. 1988. Factors controlling nutrient concentrations in Amazon floodplain lakes. Limnol. Oceanogr. 33: 41-56.

FürEDER, L. 1999. High alpine streams: Cold habitats for insect larvae, p. 181-196. In R. Margesin and F. Schinner [eds.], Cold adapted organisms: Ecology, physiology, enzymology and molecular biology. Springer.

Gurnell, A. M., AND C. R. FenN. 1985. Spatial and temporal variation in electrical conductivity in a pro-glacial stream system. J. Glaciol. 31: 108-114.

Howard-Williams, C., J. C. Priscu, and W. F. Vincent. 1989. Nitrogen dynamics in two Antarctic streams. Hydrobiologia 172: 51-61.

Hudon, C., R. Morin, J. Bunch, and R. Harland. 1996. Carbon and nutrient output from the Great Whale River (Hudson Bay) and a comparison with other rivers around Quebec. Can. J. Fish. Aquat. Sci. 53: 1513-1525.
Junk, W. J., P. B. Bayley, And R. E. Sparks. 1989. The flood pulse concept in river-floodplain systems, p. 110-127. In D. P. Dodge [ed.], Proc. Int. Large River Symp., Can. Spec. Publ. Fish. Aquat. Sci. 106.

Kaplan, L. A., And J. D. Newbold. 2000. Surface and subsurface dissolved organic carbon, p. 237-258. In J. B. Jones and P. J. Mulholland [eds.], Streams and ground waters. Academic.

Kling, G. W., G. W. Kipphut, M. M. Miller, and W. J. O'Brian. 2000. Integration of lakes and streams in a landscape perspective: The importance of material processing on spatial patterns and temporal coherence. Freshw. Biol. 46: 477-497.

Lesack, L. F. W., P. MARsh, AND P. E. Heckey. 1998. Spatial and temporal dynamics of major solute chemistry among Mackenzie Delta lakes. Limnol. Oceanogr. 43: 1530-1543.

Lewis, W. M., J. H. Melack, W. H. McDowell, M. McClain, AND J. E. RICHEY. 1999. Nitrogen yields from undisturbed watersheds in the Americas. Biogeochemistry 46: 149-162.

- , F. H. Weibezahn, J. F. SAunders, III, and S. K. HamilTON. 1990. The Orinoco river as an ecological system. Interciencia 15: 346-357.

Lock, M. A., T. E. Ford, A. J. Hullar, M. Kaufman, J. R. VesTAL, G. S. VolK, AND R. M. Ventullo. 1990. Phosphorous limitation in an Arctic river biofilm-a whole ecosystem experiment. Water Res. 24: 1545-1549

Malard, F., K. Tockner, And J. V. Ward. 1999. Shifting dominance of subcatchment water sources and flow paths in a glacial flood plain (Val Roseg, Switzerland). Arct. Antarct. Alp. Res. 31: 135-150.

- - AND 2000. A landscape-level analysis of phsyico-chemical heterogeneity in a glacial floodplain. Landsc. Ecol. 15: 679-695.

MCDowell, W. H., AND C. E. AshbuRy. 1994. Export of carbon, nitrogen, and major ions from three tropical montane watersheds. Limnol. Oceanogr. 39: 111-125.

McHale, M. R., M. J. Mitchell, J. J. McDonnell, and C. P. Cirmo. 2000. Nitrogen solutes in an Adirondack forested watershed: Importance of dissolved organic nitrogen. Biogeochemistry 48: $165-184$.

McKnight, D. M., AND C. M. TAte. 1997. Canada stream: A glacial meltwater stream in Taylor Valley, South Victoria Land, Antarctica. J. N. Am. Benthol. Soc. 16: 14-17.

Meybeck, M. 1982. Carbon, nitrogen, and phosphorous transport by world rivers. Am. J. Sci. 282: 401-450.

Milner, A. M., And G. E. Petts. 1994. Glacial rivers: Physical habitat and ecology. Freshw. Biol. 32: 295-307.

NICKUS, U., AND OTHERS. 1997. SNOSP: Ion deposition and concentration in high alpine snow packs. Tellus 49B: 56-71.

Oswood, M. W., J. G. Irons, III, AND D. M. Schell. 1996. Dynamics of dissolved and particulate carbon in an arctic stream, p. 275-289 In J. F. Reynolds and J. D. Tenhunen [eds.], Landscape function and disturbance in arctic tundra. Springer.

RiHM, B. 1996. Critical loads of nitrogen and their exceedances. Environmental Series No. 275. BUWAL.

Robertson, A. I., S. E. Bunn, P. I. Boon, And K. F. Walker. 1999. Sources, sinks and transformations of organic carbon in Australian floodplain rivers. Mar. Freshw. Res. 50: 813-29.

Robinson, C. T., AND M. O. GESSNER. 2000. Nutrient addition accelerates leaf breakdown in an alpine springbrook. Oecologia 122: 258-263.

Rodier, D. 1996. L'analyse de l'Eau, 8th ed. Dunod.

Sickman, J. O., A. LeydecKer, AND J. M. Melack. 2001. Nitrogen mass balances and abiotic controls on $\mathrm{N}$ retention and yield in high-elevation catchments of the Sierra Nevada, California, United States. Wat. Resour. Res. 37: 1445-1461.

SORANNO, P. A., AND OTHERS. 1999. Spatial variation among lakes 
within landscapes: Ecological organization along lake chains. Ecosystems 2: 395-410.

Suecker, J. K., J. N. Ryan, C. Kendall, and R. D. Jarrett. 2000. Determination of hydrologic pathways during snowmelt for alpine/subalpine basins, Rocky Mountain National Park, Colorado. Wat. Resour. Res. 36: 63-75.

Teeri, J. A., AND P. E. BARretT. 1977. Detrital transport by wind in a high arctic terrestrial ecosystem. Arct. Alp. Res. 7: 387391.

Thurman, E. M. 1985. Organic geochemistry of natural waters. Kluwer

Tockner, K., F. Malard, P. Burgherr, C. T. Robinson, U. UehLINGER, R. ZAH, AND J. V. WARD. 1997. Physico-chemical characterization of channel types in a glacial floodplain ecosystem (Val Roseg, Switzerland). Arch. Hydrobiol. 140: 433463.

AND J. V. WARD. 2000. An extension of the flood pulse concept. Hydrol. Process. 14: 2861-2883.

, D. Pennetzdorfer, N. Reiner, F. Schiemer, and J. V. WARD. 1999. Hydrologic connectivity and the exchange of organic matter and nutrients in a dynamic river-floodplain system (Danube, Austria). Freshw. Biol. 41: 521-535.

Tranter, M., G. H. Brown, A. Hodson, A. M. Gurnell, and M. J. SHARP. 1994. Variations in the nitrate concentration of glacial runoff in Alpine and Sub-Polar environments. International Association of Hydrological Sciences Publ. 233, p. 299-311.

Uehlinger, U., R. ZAH, AND H. R. BÜRGI. 1998. The Val Roseg project: Temporal and spatial patterns of benthic algae in an alpine stream ecosystem influenced by glacier runoff. IAHS Publ. 248: 419-424.

WARD, J. V. 1994. Ecology of alpine streams. Freshw. Biol. 32: 277-294.

, F. Malard, K. Tockner, and U. Uehlinger. 1999. Influence of ground water on surface water conditions in a glacial flood plain of the Swiss Alps. Hydrol. Process. 13: 277-293.

Webster, J. R., AND J. L. MeYer [EDS.]. 1997. Stream organic matter budgets. J. N. Am. Benthol. Soc. 16: 3-161.

WeIGELHOFER, G., AND J. A. WARINGER. 1994. Allochthonous input of coarse particulate organic matter (CPOM) in a first to fourth order Austrian forest stream. Int. Rev. Gesamten Hydrobiol. 79: 461-471.

Williams, M. W., A. D. Brown, and J. M. Melack. 1993. Geochemical and hydrologic controls on the composition of surface water in a high-elevation basin, Sierra Nevada, California. Limnol. Oceanogr. 38: 775-797.

, AND J. M. MELACK. 1989. Effects of spatial and temporal variation in snow melt on nitrate ion and sulfate ion pulses in melt waters within an alpine basin. Ann. Glaciol. 13: 285-288.

Wissmar, R. C., D. N. Swanston, M. Bryant, and K. McGee. 1997. Factors influencing stream chemistry in catchments on Prince of Wales Island, Alaska. Freshw. Biol. 38: 301-314.

ZAH, R., AND U. UEHLINGER. In press. Particulate organic matter inputs to a glacial stream system in the Swiss Alps. Freshw. Biol.

Received: 29 November 2000

Accepted: 22 August 2001

Amended: 19 October 2001 